\title{
PEMERTAHANAN BAHASA DAERAH SUKU BAJAU SAMMA DI KELURAHAN JENEBORA KECAMATAN PENAJAM KABUPATEN PENAJAM PASER UTARA
}

\author{
Nurun Nisah ${ }^{1}$, Kiftian Hady Prasetya ${ }^{2}$, Ari Musdolifah ${ }^{3}$ \\ Universitas Balikpapan ${ }^{1}$, Universitas Balikpapan ${ }^{2}$, Universitas Balikpapan ${ }^{3}$ \\ Pos-el: nisaanisaa13@gmail.com ${ }^{1}$, kiftian@uniba-bpn.ac.id ${ }^{2}$, ari.musdolifah@ uniba-bpn.ac.id ${ }^{3}$
}

\begin{abstract}
ABSTRAK
Zaman sekarang ini banyak bahasa daerah yang terancam punah yang disebabkan oleh penutur yang tidak memelihara bahasa daerahnya dan jumlah penuturnya lebih kecil akan mengalami kepunahan bahasa Bajau Samma mulai mengalami pergeseran bahasa. Sehingga perlunya pemertahanan bahasa Bajau Samma. Tujuan penelitian ini adalah untuk mendeskripsikan upaya pemertahanan Bahasa Bajau Samma pada masyarakat penuturnya. Penelitian ini merupakan penelitian deskriptif kualitatif Dengan menggunakan pendekatan sosiolinguistik. Data dalam penelitian ini berupa tuturun Suku Bajau Samma. Sumber data penelitian ini berasal dari data kata-kata dari bahasa bajau samma dan tindakan orang-orang yang diamati. Teknik pengumpulan data menggunakan teknik simak bebas libat cakap dan wawancara. Teknik analisis data menggunakan teknik reduksi data, penyajian data dan penarikan kesimpulan. Hasil penelitian menunjukkan upaya pemertahanan bahasa menggunakan faktor-faktor pemertahanan bahasa (1) Konsentrasi Penutur (2) Kesinambungan Pengalihan Bahasa Golongan Muda (3) Loyalitas Terhadap Bahasa Ibu (4) Sikap Bahasa Golongan Muda (5) Penggunaan Bahasa Oleh Kelompok Guyub.
\end{abstract}

\section{Kata Kunci: Sosiolinguistik, Pemertahanan Bahasa, Suku Bajau Samma.}

\begin{abstract}
In this day and age many endangered regional languages are caused by speakers who do not maintain their regional languages and the number of speakers is smaller, they will experience extinction. The Bajau Samma language begins to experience a shift in language. So the need for the preservation of the Bajau Samma language. Related to this background, the purpose of this study was to describe the efforts of the Bajau Samma language preservation to the speakers. This research is a qualitative descriptive study using a sociolinguistic approach. The data in this study were Tuturun bajau samma tribes. The source of this research data comes from the data of words from the Bajau Samma language and the actions of those observed. Data collection techniques use competent free involvement techniques and interviews. Data analysis techniques using data reduction techniques, data presentation and conclusion drawing. The results of this study indicate efforts to maintain language using language retention factors (1) Speaker Concentration (2) Continuity of Transfer of Youth (3) Loyalty to Mother's Language (4) Attitudes of Youth Language (5) Language Use by Guyub Group.
\end{abstract}

Keywords: Sociolinguistic, Preservation Language, Bajau Samma Tribe.

\section{PENDAHULUAN}

Bahasa merupakan alat komunikasi yang penting bagi manusia. Bahasa adalah suatu alat komunikasi yang digunakan dalam aktivitas kehidupan sehari-hari untuk menyampaikan ide dan pikiran kepada orang lain. Bahasa merupakan suatu 
unsur pokok yang terdapat dalam masyarakat. Bahasa yang digunakan oleh masyarakat sangat beragam diperkirakan jumlah bahasa di dunia antara 6.000 7.000 bahasa, sedangkan di Indonesia sendiri memiliki 748 bahasa dikutip dari laman (Wikipedia.com, 2010). Dari banyaknya ragam bahasa yang dimiliki Indonesia menjadikan masyarakatnya multilingual.

Masyarakat Indonesia pada umumnya multilingual. Mereka terlebih dahulu menguasai bahasa daerah sebagai bahasa pertama atau bahasa ibu. Seiring berkembangnya zaman, masyarakat berubah menjadi masyarakat yang bilingual atau multilingual. Masyarakat menguasai bahasa ibu juga menguasai bahasa Indonesia atau bahasa lain. Dampak dari masyarakat bilingual dan multilingual adalah terdapat gejala yang menimbulkan persaingan antara dua bahasa atau lebih. Pada umumnya bahasa ibu selalu kalah bersaing dari bahasa kedua. Akibatnya, bisa terjadi pergeseran ataupun punahnya suatu bahasa, sehingga, perlunya suatu pemertahanan.

Pemertahanan bahasa adalah cara untuk mempertahankan bahasa agar tidak mengalami pergeseran dan berakibat punahnya suatu bahasa. Pemertahanan bahasa lebih menyangkut sikap atau penilaian terhadap suatu bahasa, untuk tetap menggunakan bahasa tersebut di tengah-tengah bahasa lainnya (Chaer, 2010, p. 146). Pemertahanan bahasa terjadi pada suatu masyarakat bahasa yang masih terus menggunakan bahasa ibunya pada penggunaan bahasa yang biasanya secara turun temurun dikuasai oleh penutur bahasa tersebut.

Sumarsono (2017, p. 280) mengungkapkan bahwa dalam pemertahanan bahasa suatu komunitas secara kolektif menentukan untuk melanjutkan memakai bahasa yang sudah biasa dipakai. Jadi seluruh masyarakat bersama- sama melanjutkan dan mempertahankan suatu bahasa agar tidak mengalami punahnya bahasa. Zaman sekarang ini banyak bahasa daerah yang terancam punah yang disebabkan oleh penutur yang tidak memelihara bahasa daerahnya dan jumlah penuturnya lebih kecil akan mengalami kepunahan. Seperti halnya 12 bahasa yang teridentifikasi telah punah adalah Hukumina, Kayeli, Liliali, Moksela, Naka'ela, Nila, Palumata, Piru, dan Te'un di Maluku, Mapia dan Tandia di Papua, serta Tobada' di Sulawesi. Seperti halnya 12 bahasa yang telah punah, bahasa Bajau Samma mulai mengalami pergeseran bahasa. Sehingga perlunya pemertahanan. Jika kita tidak dapat mempertahankan bahasa tersebut, bisa saja bahasa Bajau Samma mengalami hal yang sama yaitu punahnya bahasa.

Nugroho (2014) menyatakan bahwa Bajau atau Sama-Bajau adalah sebuah suku atau etnik yang tidak pernah menetap pada suatu daerah tertentu. Mereka berpindah, dan selalu menjelajah menggunakan perahu pada jangka waktu tertentu. Suku Bajau banyak sekali mendiami bagian utara Kalimantan, bagian utara Sulawesi hingga perairan Maluku, dan Raja Ampat. Dikutip dari laman (Wikipedia, 2010) bahwa Suku Sama-Bajau berasal dari Kepulauan Sulu wilayah Filipina. Suku ini masih satu kerabat dengan Suku Moro yang tinggal di sana. Dari wilayah Filipina, suku ini bergerak menuju sebelah utara Kalimantan menuju Brunei, Malaysia, dan juga ke wilayah Indonesia tepatnya di ujung utara Sulawesi. Di kehidupan sehari-hari suku Bajau Samma menggunak bahasa Bajau Samma untuk berkomunikasi.

Dikutip dari laman (Wikipedia, 2010) Bahasa Bajau adalah sebutan untuk bahasa yang digunakan oleh masyarakat Suku Bajau. Bahasa Bajau termasuk dalam rumpun bahasa Barito Raya. Bajau Samma yang biasa juga disebut "Orang Laut" merupakan suku 
yang nomaden atau hidupnya berpindahpindah karena masyarakat suku Bajau Samma bersifat nomaden jadi bahasa yang digunakan terpengaruh oleh bahasa yang didapatkan dari lingkungan baru sehingga mempermudah komunikasi untuk beradaptasi masyarakat suku Bajau Samma.

Pada dasarnya, Bahasa Bajau Samma adalah alat komunikasi yang digunakan dalam keluarga dan masyarakat di daerah Kelurahan Jenebora, Kabupaten Penajam Paser Utara, terutama untuk masyarakat nelayan. Namun demikian, terjadi pergeseran sikap penutur bahasa Bajau Samma terhadap bahasa Bajau Samma itu sendiri pada sebagian masyarakat Jenebora terutama generasi muda yang tinggal di daerah tersebut karena generasi muda di Kelurahan Jenebora lebih sering menggunakan Bahasa Daerah lain atau Bahasa Indonesia sehingga perlunya pemertahanan bahasa.

Fishman (Nugroho, 2016) menyatakan bahwa salah satu faktor penting pemertahanan sebuah bahasa adalah adanya loyalitas masyarakat pendukungnya. Berdasarkan pendapat tersebut, dapat ditarik sebuah kesimpulan bahwa masyarakat di Jenebora harus memiliki loyalitas terhadap bahasa Bajau Samma, dengan loyalitas itu masyarakat mampu melestarikan bahasanya. Faktor berikutnya adalah jumlah orang yang mengakui bahasa tersebut sebagai bahasa ibu, dan penutur dewasa berbicara dengan sesamanya dalam situasi yang beragam menggunakan Bahasa Bajau Samma tersebut. Seperti hasil observasi yang ditemukan pada tuturan di bawah ini.

Berdasarkan observasi awal dan fakta di lapangan terhadap pemakaian bahasa Bajau Samma pada masyarakat nelayan di Kelurahan Jenebora, peneliti melihat kondisi masyarakat pemakaian bahasa Bajau Samma dapat mempertahankan bahasa daerahnya pada saat mereka berkomunikasi dengan sesama masyarakat Bajau maupun masyarakat umum.

$$
\begin{aligned}
& \text { Konteks: Menanyakan Hasil } \\
& \text { Tangkapan. } \\
& \text { Penutur 1: } N a \text { nginde doing }
\end{aligned}
$$

Data tersebut adalah percakapan atau komunikasi yang membahas transaksi jual beli ikan. Di situasi tersebut terdapat nelayan dan beberapa ibu. Nelayan tersebut Bersuku Bajau Samma dan ibu tersebut ada yang bersuku Bajau Samma ada juga yang tidak. Pada saat itu nelayan berkomunikasi menggunakan bahasa Bajau Samma padahal disituasi itu bukan hanya ada penutur yang berbahasa Bajau, ada juga yang tidak mengerti dan tidak menggunakan bahasa Bajau Samma. Hal tersebut dilakukan secara sadar oleh penutur agar lawan bicaranya bisa belajar memahami tuturan dalam bahasa Bajau Samma. Dari tuturan dan situasi yang tergambar. Faktor yang terjadi adanya loyalitas dari masyrakat pendukungnya itu di buktikan dari nelayan yang menggunakan bahasa Bajau Samma dalam tuturan walau nelayan tersebut tahu lawan bicaranya bukan berasal dari suku Bajau Samma.

Dari hasil yang didapatkan, peneliti tertarik untuk menganalisis kondisi pemertahanan bahasa Bajau Samma pada masyarakat di Kelurahan Jenebora. Walaupun generasi remaja sudah jarang menggunakan bahasa Bajau Samma, para generasi tua masih menggunakan bahasa Bajau. Oleh sebab itu, perlu adanya penelitian untuk mengetahui upaya apa yang dilakukan 
masyarakat Jenebora dalam pemertahanan bahasa Bajau Samma. Faktor yang terjadi, karena generasi remaja di kelurahan jenebora adalah masyarakat yang dwibahasa mereka mengetahui bahasa daerah dan juga bahasa indonesi tetapi mereka lebih sering menggunakan bahasa indonesia karena di lingkungan sekolah mereka tidak menggunakan bahasa bajau sama melainkan bahasa indonesia. Berbeda dengan generasi tua yang berada di kelurahan Jenebora mereka masih menggunakan bahasa Bajau Samma sebagai alat berkomunikasi. Saat ini generasi remaja tidak lagi menggunakan bahasa daerahnya sehingga menimbulkan dampak hilangnya atau punahnya Bahasa Daerah termasuk bahasa Bajau Samma. Dengan adanya kepunahan bahasa tersebut, maka nilai kebudayaan tradisional pun akan hilang bagi masyarakat. Jika hal tersebut dibiarkan begitu saja dan tidak segera diantisipasi, maka Bahasa Daerah dalam hal ini, bahasa Bajau Samma akan menjadi punah dan tidak dapat diteruskan, serta tidak dapat dinikmati oleh generasi berikutnya.

Faktor-faktor yang dapat mempengaruhi pemertahanan sebuah bahasa seperti yang diungkapkan oleh Sumarsono (Rahman, 2017) terbagi menjadi, yaitu sebagai berikut.

1) Konsentrasi Penutur

Bahasa hanya dapat bertahan hidup jika masih ada penutur yang memakainya. Hal ini sudah jelas dan tidak dapat dihindari. Bagi bahasa minoritas yang berada di lingkungan masyarakat yang didominasi bahasa mayoritas, yang penting adalah para penutur itu terkonsentrasi dalam suatu wilayah. Seringnya kontak fisik antarguyup memberikan kesempatan untuk melakukan interasi verbal dalam bahasa ibu mereka. Kepadatan adalah salah satu unsur konsentrasi yang mengimplikasikan rapatnya jarak fisik antarkeluarga, antar rumah, dan antarwarga. Lapangan pekerjaan juga ikut mempengaruhi konsentrasi penutur di suatu wilayah. Dalam kegiatan internal, suatu kelompok tidak perlu melibatkan orang luar kelompoknya. Konsentrasi penutur seperti itu menguntungkan bagi pemertahanan suatu bahasa. Bahasa tersebut mempunyai kesempatan yang sangat besar untuk digunakan oleh penuturnya.

2) Kesinambungan Pengalihan Bahasa Ibu

Pada umumnya seorang penutur bukan ekabahasawan, melainkan dwibahasawan karena banyak di antara mereka menguasai bahasa lain (B2), meskipun kemampuan itu hanya sekadar mampu berbicara sedikit-sedikit. Penutur asli (B1) memperoleh dan menggunakan B2 karena kebutuhan pragmatis, yaitu demi hubungan pekerjaan atau ekonomi. Dengan demikian, dapat dikatakan bahwa motivasi yang melandasi pemerolehan dan penggunaan B2 adalah motivasi instrumental bukan motivasi integratif. Kondisi seperti itu tentu sangat menguntungkan dalam proses pemertahanan sebuah bahasa. Anakanak mereka tidak harus menjadi dwibahasawan pada usia muda sehingga pemertahanan bahasa dapat berlanjut. Proses pengalihan B1 meskipun dilakukan di bawah kesadaran kepada generasi berikutnya, jelas merupakan wujud nyata dari kesetiaan generasi tua terhadap BI. Perilaku ini merupakan faktor penting dalam pemertahanan dan pelestarian bahasa itu, sehingga tidak tergeser oleh bahasa mayoritas. Pemertahanan ini makin kuat karena ditunjang oleh tidak adanya keperluan mengalihkan bahasa lain, khususnya B2 kepada anak-anak mereka.

3) Loyalitas terhadap Bahasa Ibu

Bahasa sebagai lambang identitas kelompok atau guyup yang memilikinya. Proses pengalihan bahasa kepada generasi berikutnya jelas menggambar kesetiaan generasi tua terhadap bahasanya. Loyalitas atau 
kesetiaan terhadap B1 makin jelas manakala penuturnya menjelaskan alasan yang melandasi pengalihan B1. Jika generasi tua mengalihkan B1 kepada generasi muda dengan cara pengungkapan yang berbeda-beda. Hal ini sangat mempengaruhi dalam pemertahanan suatu bahasa. Selain itu, generasi muda juga harus memiliki kesadaran yang tinggi terhadap penggunaan B1 sesuai dengan proporsinya. Artinya, generasi muda harus mengetahui kapan harus menggunakan B1 dan kapan menggunakan B2.

4) Sikap Bahasa Golongan Muda

Demi pemertahanan bahasa, golongan muda harus memiliki sikap positif terhadap B1-nya. Mereka harus memiliki loyalitas terhadap penggunaan bahasa ibunya dengan menempatkannya pada posisi yang pas meskipun tidak menutup kemungkinan memerlukan bahasa lain. Sikap bahasa seorang penutur sebuah bahasa memang tidak bisa diamati secara empiris. Sikap yang menyangkut batin dapat diduga dari tindakan dan perilaku Sikap bahasa golongan muda diharapkan lebih luas dibandingkan dengan golongan tua.

5) Penggunaan bahasa oleh kelompok (Guyup)

Dalam penggunaan bahasa oleh dwibahasawan, pilihan bahasa mana yang dipakai dalam situasi tertentu merupakan kajian menarik. Dalam penelitian ini penggunaan bahasa yang terkait dengan pilihan bahasa dibatasi pada ranah keluarga (family domain), ketetanggaan (neighborhood domain), pendidikan (education domain), agama (religion domain), transaksi (transactional domain), dan pemerintahan (government domain).

Ratna, (2003) menyatakan masyarakat Bajau adalah masyarakat yang lebih banyak berkecimpung dengan laut. Awalnya masyarakat Bajau bertempat tinggal di atas perahu. Untuk memenuhi kebutuhan sehari-hari sebagai nelayan, mereka hidup mengembara dari satu tempat ke tempat lainnya sesuai dengan keberadaan sumberdaya laut yang ditangkap dan musim. Biasanya mereka ke darat untuk menjual atau menukar hasil tangkapannya dengan kebutuhan pangan dan sandang. Kesempatan itu dipakai juga untuk mengambil air tawar dan kayu api. Pada kesempatan lain, yaitu paling tidak enam bulan sekali atau pada saat angin berembus kencang, mereka mendarat untuk memperbaiki perahu atau membuat perahu baru. Meskipun demikian, pada saat ini sebagian besar orang Bajau sudah tinggal menetap di sepanjang pantai.

Wikipedia.com

menyebutkan bahwa Suku Bajau atau Suku Sama adalah suku bangsa yang tanah asalnya Kepulauan Sulu, Filipina Selatan. Suku ini merupakan suku nomaden yang hidup di atas laut, sehingga disebut gipsi laut. Suku Bajau menggunakan bahasa Sama- Bajau.

Wikipedia.com

(2010)

menyatakan bahwa Suku Bajau sejak ratusan tahun yang lalu sudah menyebar ke negeri Sabah dan berbagai wilayah Indonesia. Suku Bajau juga merupakan anak negeri di Sabah. Suku-suku di Kalimantan diperkirakan bermigrasi dari arah utara (Filipina) pada zaman prasejarah. Suku Bajau yang Muslim ini merupakan gelombang terakhir migrasi dari arah utara Kalimantan yang memasuki pesisir Kalimantan Timur hingga Kalimantan Selatan dan menduduki pulau-pulau sekitarnya, lebih dahulu daripada kedatangan suku-suku Muslim dari rumpun Bugis yaitu suku Bugis, suku Makassar, suku Mandar. Saat ini, Suku Bajau menyebar hampir di seluruh kepulauan Indonesia (terutama Indonesia Timur), bahkan sampai ke Madagaskar. Kebanyakan Suku Bajau yang menyebar mulai tinggal menetap dan berbaur dengan suku-suku lain.

Seperti Suku Bajau yang terdapat di kepulauan Maratua telah melekat 
dengan budaya Indonesia sehingga telah jauh berbeda dengan bajau Sulu, Filipina. Maksudnya disini, berbeda secara bahasa, logat/intonasi dalam berbicara, dan keyakinan masyarakan setempat. Bajau Maratua juga memiliki kehidupan yang dapat dikatakan layak.

Bahkan memiliki pekerjaan dan pendidikan yang tinggi. Masyarakat Suku bajau Maratua mayoritas menganut agama islam. Tidak ada yang menganut kepercayaan animisme maupun ateis. Suku bajau Maratua juga tinggal atau bermukim di atas tanah dengan membuat rumah- rumah sederhana yang layak ditempati, berbeda dengan bajau laut Sulu, Filipina yang tinggal di atas permukaan laut dan beraktifitas di dalam perahu sehingga disebut juga sebagai "Pala'U" atau dalam bahasa indonesia artinya perahu. Bajau Maratua ini juga mengenal tulisan dan bacaan sehingga tak heran banyak dari anak-anak suku bajau menganyam pendidikan ke jenjang yang lebih tinggi. Bajau Maratua ini adalah Bajau modern karena kehidupan yang telah modern, memiliki keyakinan, menganyam pendidikan, bermukim di atas tanah dan bersosialisasi seperti masyarakat pada umumnya.

Suku Bajau memiliki setidaknya 10 bahasa yang diturunkan dari bahasa induk Sama-Bajau. Secara garis besar suku ini banyak menggunakan bahasa Sinama. Namun, bahasa ini sering disebut sebagai Bahasa Bajau karena dipakai hampir di semua suku dan turunannya. Bahasa yang dipakai ini cenderung mirip dengan Tagalog karena mereka berasal dari Filipina. Namun suku-suka yang berada di area Malaysia, Brunei, dan Indonesia menggunakan bahasa yang ada campurannya dengan bahasa setempat. (Nugroho, 2016, p. 5).

Hampir semua orang di suku Sama Bajau bisa bahasa lokal tempat mereka singgah karena keperluan jualbeli barang, biasanya orang yang ada di Suku bajau bisa lebih dari satu bahasa.
Pertama adalah bahasa yang digunakan sehari-hari dan kedua adalah bahasa yang digunakan untuk keperluan bersosialisasi dengan penduduk lokal.

Suku Bajau Samma yang berada di kelurahan Jenebora memiliki beberapa karakteristik. Pertama, masyarakat suku Bajau Samma mayoritas adalah seorang nelayan. Sesuai dengan asal-usul mereka yang nenek moyang suku Bajau Samma adalah seorang pelaut yang hidupnya nomaden dan hidup di atas laut. Kedua, lokasi pemukiman suku Bajau Samma yang ada di Kelurahan Jenebora beradi di bibir pantai.

\section{METODE PENELITIAN}

Pendekatan penelitian yang digunakan dalam penelitian ini adalah pendekatan sosiolinguistik. Pendekatan sosiolinguistik mengkaji bahasa dalam kaitannya dalam penggunaan bahasa dalam masyarakat Chaer (2010, p. 3). Penelitian ini menggunakan pengantar sosiolinguistik karena menganalisis penggunaan bahasa Bajau Samma pada masyarakat kelurahan Jenebora. Pendekaxatan sosiolinguistik difokuskan pada masalah pergeseran dan pemertahanan bahasa. Pendekatan sosiolinguistik digunakan karena dilatarbelakangi dengan fokus penelitian yang bertujuan untuk mengetahui faktorfaktor penyebab pergeseran dan pemertahanan Bahasa Bajau Samma pada nelayan di Kelurahan Jenebora.

Adapun jenis penelitian ini adalah deskriptif kualitatif. Bogdan \& Taylor (Sujarweni, 2014, p. 19) mendefinisikan penelitian kualitatif sebagai prosedur penelitian yang menghasilkan data deskriptif berupa kata-kata tertulis atau lisan dari orang-orang dan perilaku yang dapat diamati sehingga dapat menghasilkan uraian yang mendalam mengenai ucapan, tulisan, dan atau perilaku yang dapat diamati dari suatu individu ataupun kelompok masyarakat tertentu dalam suatu konteks tertentu 
yang dikaji dari sudut pandang yang utuh, komperehensif, dan holistik. Jenis penelitian deskriptif kualitatif yang digunakan pada penelitian ini bertujuan untuk memperoleh informasi berupa kata-kata untuk menjelaskan objek penelitian peran pemertahanan Bahasa Bajau Samma pada masyarakat nelayan Jenebora secara mendalam dan komprehensif.

Data dari penelitian ini adalah tuturan yang mengandung bahasa Bajau Samma dari suku Bajau Samma pada masyarakat Jenebora. Penelitian ini menggunakan sumber data kata-kata dari bahasa bajau samma dan tindakan orangorang yang diamati. Sumber data utama dicatat melalui catatan tertulis atau melalui perekaman video/audio, pengambilan foto, atau film.

Data yang diperoleh dalam penelitian ini bersumber dari pengamatan langsung pada masyarakat bahasa Bajau Samma yang diteliti. Sumber data dalam penelitian ini adalah masyarakat suku Bajau Samma di Kelurahan Jenebora. Jenebora adalah salah satu kelurahan di Kecamatan Penajam, Kabupaten Penajam Paser Utara, Kalimantan Timur, Indonesia. Jumlah penduduknya sekitar 1500 jiwa. Terdapat 13 RT dan mayoritas masyarakatnya berkerja sebagai nelayan.

Sumber data diperoleh dari masyarakat suku Bajau Samma yang berada di Kelurahan Jenebora Kecamatan Penajam Kabupaten Penajam Paser Utara dengan difokuskan kepada RT 01，02，03，10,13. Subjek dalam penelitian ini menyangkut data penggunaan bahasa Bajau Samma, dibagi dalam tiga kelompok.Yang pertama berusia antara 28-63 tahun. Kelompok kedua adalah golongan muda berusia antara 17-27 tahun, dan kelompok usia 7-16. Penelitian ini di fokuskan kepada masyarakat yang bekerja sebagai nelayan.

Dalam penelitian ini, instrumen yang digunakan adalah alat pedoman wawancara dan didukung dengan sejumlah instrumen lainnya seperti buku catatan untuk mencatat hal-hal penting yang menunjang kelancaran penelitian; handphone yang akan digunakan untuk merekam informasi dan pendapat informan yang berkaitan dengan masalah penelitian pemertahanan bahasa daerah Suku Bajau Samma, serta kamera berfungsi untuk mendokumentasikan kegiatan-kegiatan penelitian yang dilakukan.

\section{HASIL DAN PEMBAHASAN Hasil Penelitian}

Hasil penelitian yang dijelaskan dalam penelitian ini adalah upaya pemertahanan bahasa daerah suku Bajau Samma pada masyarakat Kelurahan Jenebora Kecamatan Penajam Kabupaten Penajam Paser Utara. Sejalan dengan masalah yang ada dalam penelitian, maka penelitian ini bertujuan mendeskripsikan upaya pemertahanan bahasa Bajau Samma pada masyarakat penuturnya. Data dalam penelitian ini adalah tuturan yang mengandung bahasa Bajau Samma dari suku Bajau Samma pada masyarakat Jenebora.

Data yang telah diperoleh, selanjutnya dianalisis dan dikaitkan dengan teori yang digunakan untuk dibahas dipembahasan. Adapun hasil penelitian yang di temukan berdasarkan faktor-faktor pemertahanan bahasa adalah (1) Kosentrasi Penutur, (2) Kesinambungan Pengalihan Bahasa Ibu, (3) Loyalitas Terhadap Bahasa Ibu, (4) Sikap Bahasa Golongan Muda, (5) Penggunaan Bahasa Oleh Kelompok (Guyup).

\section{Pembahasan}

\section{Konsentrasi Penutur}

Bahasa hanya dapat bertahan hidup jika masih ada penutur yang memakainya. Hal ini sudah jelas dan tidak dapat dihindari. yang penting adalah para penutur itu terkonsentrasi 
dalam suatu wilayah. Seringnya kontak fisik antarguyup memberikan kesempatan untuk melakukan interasi verbal dalam bahasa ibu mereka. Kepadatan adalah salah satu unsur konsentrasi yang mengimplikasikan rapatnya jarak fisik antarkeluarga, antar rumah, dan antarwarga. Lapangan pekerjaan juga ikut mempengaruhi konsentrasi penutur di suatu wilayah. Dalam kegiatan internal, suatu kelompok tidak perlu melibatkan orang luar kelompoknya. Konsentrasi penutur seperti itu menguntungkan bagi pemertahanan suatu bahasa. Bahasa tersebut mempunyai kesempatan yang sangat besar untuk digunakan oleh penuturnya. (Sumarsono, 1993, p. 154).

\section{Konteks: percakapan berlansung antara empat penutur suku Bajau Samma yang membicarakan lokasi untuk melaut ikan percakapan berlangsung di jembatan persinggahan kapal (Dermaga)}

Penutur 1: anu lalam ma dialam, nge gas te aa pabarit miye,di Neneng iye, ngegas te lopat, yo nu ge (Dalam dalamnya, orang lewat di situ ngegas, di Nenang, ngegas kamu bilang )

Penutur 2: nia jambatan? (ada jembatan?)

Penutur 1: jambatan iye terus $k a$ dalam lagi (Jembatan itu terus didalam lagi)

Penutur 3: aa Pantei Langei teng ngase miye (Orang Pantai Lango sering masuk kesitu)

Penutur 2: pase ka dialam (Masuk ke dalam)

Penutur 1: sa yoyi anu si Dobing di gerak biese ye (Tidak ada si Dobing biasanya dia dimarahin)

Penutur 4: odeng de je dandangan ne (Udang saja sendirian)

Penutur 1: $\quad$ man pangempeng mere, sa bahaani dah balei di teguran (Di sana tempat empang tidak berani sudah dimarahin)

Penutur 2: tegalku mapatabe ma bagian ne Tur (Lamanya aku hanyut di daerah itu Tur)
Data tersebut adalah percakapan yang berlangsung antara empat penutur yang sedang membicarakan lokasi untuk melaut penutur (1) menjelaskan bahwa lokasi tersebut jauh di dalam dan orangorang tidak berani ke lokasi tersebut karena sering mendapat teguran dari warga sekitar. Penutur (1) juga menjelaskan bahwa lokasi tersebut adalah lahan empang.

Tuturan tersebut termasuk dalam faktor-faktor pemertahanan bahasa yakni konsentrasi penutur karena saat melakukan tuturan tidak diperlukan kelompok lain dibuktikan dengan keempat penutur menggunakan bahasa Bajau Samma. Kegiatan berbincangbincang tersebut sering dilakukan oleh kelompok masyarakat nelayan untuk saling bertukar informasi sehingga terjadinya konsentrasi penutur.

Dari kedua data yang menunjukan kegiatan tersebut sering dilakukan oleh para nelayan di Kelurahan Jenebora terutama warga suku Bajau Samma jika setelah melaut mereka akan saling bercengkrama apalagi jika cuaca buruk yang mengharuskan nelayan tidak pergi ke laut untuk mencari ikan. Waktu tersebut di gunakan untuk memperbaiki mesin kapal yang rusak. Para nelayan yang ada di Kelurahan Jenebora adalah mayoritas bersuku Bajau Samma sehingga adanya kosentrasi penutur karena saat melakukan tuturan tidak di perlukan kelompok lain sehingga penutur tersebut menggunakan bahasa Bajau Samma saat berkomunikasi.

Berdasarkan pengamatan peneliti dan wawancara, salah satu faktor pendukung pemertahanan bahasa Bajau Samma di kelurahan Jenebora Kecamata Penajam Kabupaten Penajam Paser Utara adalah jarak fisik antarkeluarga dalam hal ini adalah kedekatan dan seringnya kontak fisik antara keluarga satu dengan yang lainnya. Kedekatan jarak fisik antarkeluarga suku Bajau Samma diwujudkan dalam jalinan 
silaturahmi, saling berbagi, saling tolong-menolong, dan gotong royong. Jarak fisik yang demikian itu tidak menimbulkan kesulitan bagi warga suku Bajau Samma untuk saling berinteraksi dalam kehidupan sehari-hari. Dalam setiap pertemuaan baik kegiatan sosial maupun lainnya mereka selalu bertutur dengan bahasa Bajau Samma. Begitulah, konsentrasi penutur bahasa Bajau Samma memberi keuntungan besar bagi pemertahanan bahasa Bajau Samma. Bahasa mempunyai kesempatan sangat besar untuk dipakai oleh penuturnya dan hal itu terjadi karena dalam kegiatan suku Bajau Samma tidak perlu melibatkan orang luar guyup.

\section{Kesinambungan Pengalihan Bahasa Ibu}

\begin{tabular}{crr}
\multicolumn{2}{c}{ Kesinambungan pengalihan } \\
bahasa ibu adalah
\end{tabular} kesinambungan pengalihan bahasa ibu dari generasi terdahulu ke generasi berikutnya karena adanya loyalitas tinggi, maka generasi tua mewariskan bahasa tersebut ke generasi muda berikutnya sehingga terjadi kesinambungan pengalihan bahasa Ibu (Sumarsono, 1993, p. 156).

Konteks: percakapan berlansung antara tiga penutur. suami yang menyuruh istrinya untuk menyiapkan makan. pada malam hari di rumah salah satu warga

\footnotetext{
Penutur 1: "oh ma ulpa, di pasidean da intaan iye, dah lapar kita tu, anek nu dah lapar udah." (oh ma ulpa, di siapkan sudah makanan itu, sudah lapar ini, anak mu sudah lapar)

Penutur 2: "ehe suweng daloon, mbone pasadian itu. Sabar the daloon. Oh ija nginta ne mitu palew nu epak nu." (iya sebentar dulu, baru si siapin ini, sabar dulu. Ija makan sini panggilkan bapakmu)

Penutur 3: "oh pak nginta dah mitu." (pak makan sudah sini)
}

\begin{abstract}
Penutur 1: "ehe sueng daloon makei badu daloon tu, nah nginta dah kita mitu seme-seme, alanu pinggan iye, nginta de seme- seme kite" (iya sebentar dulu ini pakai baju dulu. Nah makan kita samasama di sini, ambil piring itu, makan sama-sama kita)
\end{abstract}

Data tersebut adalah percakapan yang berlangsung antara (3) penutur terdiri dari antara suami, istri dan anak. Maksud dari tuturan tersebut adalah suami yang menyuruh istrinya untuk menyiapkan makanan kemudian istrinya menyuruh anaknya untuk memanggil ayahnya karena makanannya sudah di sediakan, saat istri menyuruh anaknya memanggilkan ayahnya istri tersebut menggunakan bahasa Bajau Samma dan anak tersebut memanggil ayahnya dengan bahasa Bajau Samma pula, kemudian suami menjawab pula dengan bahasa Bajau Samma. Tuturan tersebut merupakan faktor-faktor pemertahanan bahasa yakni kesinambungan pengalihan bahaasa ibu karena generasi tua Bajau Samma mewariskan bahasa Bajau Samma untuk generasi muda sejak dini dalam ranah keluarga sehingga anak-anak mereka tidak harus menjadi dwibahasa pada usia muda sehingga pemertahanan bahasa dapat berlanjut.

Dari hasil data yang diperoleh golongan tua suku Bajau Samma mengaku mengalihkan bahasa Bajau Samma kepada anak-anak mereka untuk melestarikan bahasa dan budaya Bajau Samma dan mengaku mengalihkan bahasa Bajau Samma kepada anak-anak mereka karena bahasa Bajau Samma merupakan bahasa sehari-hari sehingga bahasa Bajau Samma dapat bertahan sampai dengan sekarang. Bahasa yang paling dikuasai, bahasa yang digunakan, dan dialihkan kepada golongan muda suku Bajau Samma.

Sejalan dengan hasil wawancara peneliti dengan salah satu warga Kelurahan Jenebora "Dalam sehari- 
hari kita menggunakan bahasa Bajau dan juga aku ma ruma pabahum ma dakane babahasa samma, bajau samma duangan kaluarga tetap aku menggunakan bahasa Samma karena terbiasa membicerean behese Samma karena behese Samma itu lebih alap kite ngerjean bahum ma keluarga-keluarga ke memonne daa diabann behese samma, bahasa Samma tetap bahasa indonesia juga tetap kita gunakan"

(Wawancara, Ali 20 Juli 2018).

Terjemahan:

"Dalam sehari-hari kita menggunakan bahasa Bajau dan juga saya dirumah memberitahu anak-anak berbahasa Samma, Bajau Samma dengan keluarga tetap aku menggunakann bahasa Samma karena terbiasa membicarakan bahasa Samma karena bahasa Samma itu lebih bagus kita kerjakan beri tahu semua keluargakeluarga jangan ditinggalkan bahasa Samma. Bahasa Samma tetap kita gunakan bahasa Indonesia juga tetap kita gunakan" (Wawancara, Ali 20 Juli 2018).

\section{Loyalitas Terhadap Bahasa Ibu}

Bahasa sebagai lambang identitas kelompok atau guyup yang memilikinya. Proses pengalihan bahasa kepada generasi berikutnya jelas menggambar kesetiaan generasi tua terhadap bahasanya. Loyalitas atau kesetiaan terhadap Bahasa ibu makin jelas manakala penuturnya menjelaskan alasan yang melandasi pengalihan Bahasa ibu. Jika generasi tua mengalihkan Bahasa ibu kepada generasi muda dengan cara pengungkapan yang berbeda- beda. Hal ini sangat mempengaruhi dalam pemertahanan suatu bahasa. Selain itu, generasi muda juga harus memiliki kesadaran yang tinggi terhadap penggunaan Bahasa ibu sesuai dengan proporsinya. Artinya, generasi muda harus mengetahui kapan harus menggunakan Bahasa ibu dan kapan menggunakan Bahasa kedua. (Sumarsono, 1993, p. 160).

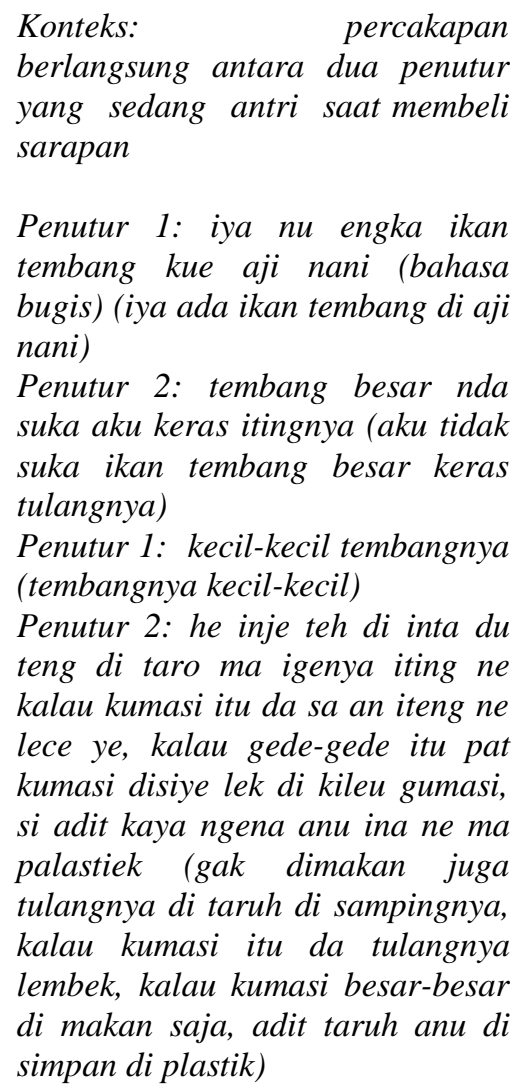

Data tersebut adalah percakapan yang terjadi antara dua penutur menceritakan penutur (1) yang memberi tahu penutur (2) jika ada ikan di rumah Aji Nani penutur (1) menggunakan bahasa Bugis saat bertutur, kemudian dijawab oleh penutur (2) bahwa dia tidak menyukai ikan tembang yang berukuran besar karena menurutnya tulang ikannya keras, penutur (2) menggunakan bahasa Bajau Samma, kemudian penutur (1) menjawab dengan bahasa Indonesia kecil-kecil tembangnya, dapat diartikan penutur (1) mengerti apa yang dimaksud penutur (2) walaupun penutur (2) menggunakan bahasa Bajau Samma.

Tuturan tersebut termasuk pada loyalitas bahasa karena adanya kesetiaan penuturnya dibuktikan dengan saat penutur (1) berkomunikasi dengan bahasa Bugis penutur (2) menjawabnya dengan berbahasa Bajau Samma walaupun terjadinya campur kode. 
Tetapi penutur (1) tetap mengerti maksud penutur (2).

Upaya atau strategi untuk mempertahankan bahasa Bajau Samma di Kelurahan Jenebora, Kecamata Penajam, Kabupaten Penajam Paser Utara. yaitu loyalitas atau kesetiaan terhadap bahasa ibu dari masyarakat pendukungnya, maka suatu bahasa akan hidup dan mewariskan bahasa tersebut dari generasi ke generasi berikutnya. Sejalan dengan Fishman (Sumarsono, 1993, p. 17) menyebutkan bahwa salah satu faktor penting pemertahanan sebuah bahasa adalah adanya loyalitas masyarakat pendukungnya. Dengan loyalitas itu, pendukung suatu bahasa akan tetap mewariskan bahasanya dari generasi ke generasi.

Tingginya loyalitas masyarakat Bajau Samma terhadap bahasanya terbukti dari orang tua pasangan (suamiistri) masyarakat Bajau Samma tetap teguh mengajarkan bahasa ibu atau bahasa Bajau Samma kepada anakanaknya di dalam rumah, kondisi inilah yang paling dominan. Loyalitas bahasa merupakan faktor penting dalam pemertahanan bahasa. Artinya, sikap loyal itu sebagaimana sikap pada umumnya dapat merupakan sesuatu yang tidak dapat diamati, tetapi karakteristiknya dapat disimpulkan dari tingkah laku yang dapat diamati.

Loyalitas terhadap bahasa Bajau Samma dapat dilihat dari tingkah laku penutur yang cenderung menggunakan bahasa Bajau Samma, menggunakan dan mengajarkan bahasa Bajau Samma kepada anak-anaknya di dalam rumah dalam kehidupan sehari-hari. Selain itu, loyalitas bahasa juga merupakan faktor pendukung pemertahanan sebuah bahasa, yaitu dengan adanya loyalitas masyarakat pendukungnya. Artinya, dengan loyalitas itu, pendukung suatu bahasa akan tetap mewariskan bahasa Bajau Samma dari generasi ke generasi.
Masyarakat penutur bahasa Bajau Samma di Kelurahan Jenebora sudah memiliki kesetiaan yang tinggi terhadap bahasanya. Kesetiaan terhadap bahasa Bajau Samma tersebut disebabkan karena masyarakat penutur bahasa Bajau Samma merasa bangga dan suka terhadap bahasa yang dimilikinya dan menjadi lambang identitas diri masyarakat Bajau Samma di Kelurahan Jenebora. Loyalitas atau kesetiaan terhadap bahasa Bajau Samma oleh masyarakat suku Bajau Samma di Kelurahan Jenebora tersebut semakin jelas pada saat mereka ditanya kebanggaan dan rasa suka mereka terhadap bahasa Bajau Samma.

\section{Sikap Bahasa Golongan Muda}

Demi pemertahanan bahasa, golongan muda harus memiliki sikap positif terhadap B1-nya. Mereka harus memiliki loyalitas terhadap penggunaan bahasa ibunya dengan menempatkannya pada posisi yang pas meskipun tidak menutup kemungkinan memerlukan bahasa lain. Sikap bahasa seorang penutur sebuah bahasa memang tidak bisa diamati secara empiris. Sikap yang menyangkut batin dapat diduga dari tindakan dan perilaku Sikap bahasa golongan muda diharapkan lebih luas dibandingkan dengan golongan tua (Sumarsono, 1993, p. 170).

Konteks: tuturan terjadi disebrang jalan terdapat empat penutur anak muda yang sedang kumpul-kumpul dan berbincang-bincang mengenai media sosial yang mereka gunakan

Penutur 1: sa to'o sa kowe ta buke facebook ku (tidak betul, tidak bisa terbuka facebook $\mathrm{ku}$ )

Penutur 2: alah gangguan (gangguan)

Penutur 1: ayeh sa kowe update status aku (aku tidak bisa update status)

Penutur 3: ganguan indosat, aku coba pakei kartu telkomsel bisa tadi (gangguan indosat, tadi aku coba pakai kartu telkomsel bisa) 


\section{Penutur 1: sa yoyi kartu telkomselku (aku tidak punya kartu telkomsel)}

Data di atas merupakan tuturan yang dilakukan emapat penutur yang sedang berkumpul dan berbincangbincang mengenai media sosial yang mereka gunakan penutur (1) memberi pernyataan bhawa dia tidak dapat mebuka akun facebooknya kemudian penutur (2) dan (3) mnjelaskan bahwa ada ganguan jaringan sehinga aplikasi tersebut tidak bisa terbuka. Tuturan tersebut sikap bahasa golongan muda adanya sikap positif yang dimiliki generasi remaja untuk menggunakan bahasa Bajau Samma.

Mengenai penjelasan tentang sikap bahasa generasi muda Bajau Samma di kelurahan Jenebora dapat memberi gambaran bahwa generasi muda Bajau Samma memiliki kemampuan dan kekayaan bahasa yang berbeda-beda. Seperti yang peneliti amati saat penelitian berlangsung bahwa generasi muda Bajau Samma di Kelurahan Jenebora selalu menggunakan Bahasa Bajau Samma dalam setiap kegiatan, seperti bercakap dengan generasi yang lebih tua, gotong-royong, dan saat berkomunikasi dengan teman sebayanya, sehingga dari penjelasan di atas dapat dismpulkan bahwa sikap bahasa golongan muda Bajau Sama di Kelurahan Jenebora pada dasarnya sama dengan generasi tua Bajau Samma di Kelurahan Jenebora, yaitu bahasa Bajau Samma sebagai bahasa ibu, bahasa Indonesia merupakan bahasa kedua bagi mereka.

Sikap bahasa golongan muda Bajau Samma di Kelurahan Jenebora tidak menyurutkan rasa bangga dan kesadaran mereka terhadap bahasa Bajau Samma, karena memiliki ikatan batin terhadap bahasa ibunya sehingga bahasa Bajau Samma dapat bertahan sampai sekarang.

\section{Penggunaan Bahasa Oleh Kelompok (Guyup)}

Dalam penggunaan bahasa oleh dwibahasawan, pilihan bahasa mana yang dipakai dalam situasi tertentu merupakan kajian menarik. Dalam penelitian ini penggunaan bahasa yang terkait dengan pilihan bahasa dibatasi pada ranah keluarga (family domain), ketetanggaan (neighborhood domain), pendidikan (education domain), agama (religion domain), transaksi (transactional domain), dan pemerintahan (government domain) (Sumarsono, 1993, p. 170).

\section{a. Ranah Keluarga}

Ranah keluarga merupakan domain terpenting dalam melihat pemertahanan sebuah bahasa, khususnya bahasa Bajau Samma di Kelurahan Jenebora keluarga merupakan ranah pertama yang dijumpai oleh seorang anak. Dari ranah keluarga akan terbentuk pribadi, watak, dan juga bahasa.

Konteks: Percakapan berlangsung antara tiga penutur suku Bajau Samma yang sedang duduk-duduk di ruang tamu dan membicarakan mengenai masa kecilnya dulu.

Penutur 2: kaam ka waktu diki di minje? dilahirkan minje man'ne? (kamu ka waktu kecil dimana? dilahirkan di mana tempatnya?

Penutur 1: Pantei Langei, lahir ma pantei langei mbok ne pindah $\mathrm{ka}$ jenebora dah basar (Pantai Lango, lahir di Pantai Lango pas sudah besar baru itu pindah ke jenebora) Penutur 2: nginey meke pindah ka jenebora? (kenapa pindah ke jenebora?)

Penutur 1: hj dari ngusir (di usir Hj Dari)

Penutur 3: seneen lagi (kasihannya)

Penutur 2: jadi usir aa mere, seneen pedi lagi (di usir orang sana, kasihan sakitnya)

Penutur 1: pedi lagi di usir kanteu pantei langei (sakitnya di usir dari Pantai Lango)

Penutur 2: di usir, lahat ka jenebora (di usir, ke jenebora) 
Penutur 1: padahal habis pondokpondok man kakuri di benteng, namun sa dadi malam tu ditimbek yok ne aji sita, kite le duan nangis-nangis ke, tepah kelaut iru (padahal habis mainan rumahrumahan di bawa, kalau tidak jadi malam ini ditembak katanya aji sita, kita jalan sambil nangis, sampai ke laut itu)

Penutur 2: pedi dulu kita nur nenek itu disuruh pindah disini (dulu kita sakit nur, nenek di suruh pindah di sini)

Penutur 1: kalo nda pindah di timbek, aku diambil aku ole ne aji sita dekat mesjid main-mainan kengke sosol (di tembak jika tidak pindah, aku diambilnya ne Aji Sita dekat masjid, lagi main kengke sosol)

Data tersebut adalah percakapan yang berlangsung antara tiga penutur terdiri dari kakak beradik dan satu keponakan mereka. Tuturan tersebut terjadi di rumah saat mereka sedang membicarakan masa kecil mereka awalnya penutur (2) bertanya kepada penutur (1) dimana dia tinggal dulu, kemudian penutur menceritakan dia dulu tinggal di Pantai Lango (Pantai Lango adalah kelurahan yang bersebelahan dengan Kelurahan Jenebora) tapi karena suatu kejadian yang mengharuskan mereka harus pindah ke Jenebora. Penutur (1) menceritakan masa kecilnya menggunakan bahasa Bajau Samma dan semua penutur yang terlibat berbicara menggunakan bahasa Bajau Samma.

Tuturan tersebut adalah pennggunaan bahasa oleh kelompok Guyub dan penggunaan bahasa antar keluarga dibuktikan dengan percakapan mereka yang membicaran masa kecil mereka dan kedua penutur tersebut adalah bersaudara. Sehingga tutran termasuk dalam ranah keluarga.

Upaya pemertahanan bahasa Bajau Samma tidak terlepas dari yang dituturkan seseorang pada saat dan tempat tertentu dalam kegiatan sehari- hari masyarakat Bajau Samma. Bahasa secara umum berfungsi sebagai alat komunikasi dalam interaksi masyarakat. Bahasa Bajau Samma sebagai Bahasa daerah suku Bajau Samma juga memiliki fungsi yang sama dengan bahasa pada umumnya, yaitu sebagai alat komunikasi khususnya dalam interaksi masyarakat di Kelurahan Jenebora umumnya dan khususnya masyarakat suku Bajau Samma.

Bahasa Bajau Samma sebagai pengantar komunikasi dalam kegiatan masyarakat suku Bajau Samma di Kelurahan Jenebora. Pada dasarnya bahasa Bajau Samma dapat digunakan sebagai bahasa pengantar dalam interaksi masyarakat, maupun alat komunikasi dalam ranah keluarga. Keluarga dalam kaitannya dengan konteks di atas, dapat dipahami sebagai wadah bagi anggotanya untuk berkomunikasi, karena keluarga merupakan tempat pertama bagi seseorang untuk belajar sesuatu (yang berhubungan dengan kegiatan bersama). Dengan komunikasi anggota keluarga dapat saling memahami antara orangtua dengan anak, atau sebaliknya antara anak dan orangtua, juga antara anggota satu keluarga dengan anggota keluarga lain. Keluarga akan menjadi sepi tanpa adanya komunikasi. Komunikasi dalam hal ini bisa diartikan seperti situasi ketika berkumpul di rumah, bercanda gurau, saling berbagi cerita sehari-hari, berbagi pengalaman maupun ketika meminta pendapat dari anggota keluarga lainnya (berunding dan berdiskusi).

b. Ranah Ketetanggaan

Ranah ketetanggan merupakan salah satu ranah yang penting dalam mengetahui pemertahanan bahasa, khususnya bahasa Bajau Samma di Kelurahan Jenebora. Dari ranah ketetanggaan dapat dilihat ketika masyarakat suku Bajau Samma berkomunkasi dengan lingkungan tetangga, baik dengan sesama suku 
ataupun dengan yang bukan sesama suku.

Konteks: percakapan berlangsung antara tiga penutur suku bajau samma yang membicarakan tetangga yang sedang sakit tuturan terjadi di depan rumah salah satu penutur.

Penutur 1: nginey da siminah akane? (kenapa sudah kabarnya simina?)

Penutur 2: masih, masih ma ICU, diingkatan te ye (masih, masih di ICU, diikat dia)

Penutur 1: teng ma pagaga, miru je teng ngowek-ngowek yo ne si anu (mau ngelawan dia, disini saja teriak-teriak katanya si anu)

Penutur 2: ehe tapi sa kowe pundu apo ye (iya tapi tidak bisa bangun dia)

Penutur 1: lema urat ne, balei batiru ye du ma ICU ye, ehe ye? (lemah uratnya, pernah begitu juga dia di ICU, Iya kan?

Penutur 2: laju beteng kanoon ye. Ta'o je itu (langsung hamil dia katanya. Tidak tau kalau ini) Penutur 1: pa itu paseng KB ge ye ? (ini paseng $K B$ kah dia?)

Penutur 2: paseng KB ge ye ma? (pasang KB kah dia Ma?)

Penutur 3: KB hari itu telat dia (hari itu dia telat KB)

Penutur 1: sa ge beteng ye lagi? (tidak kah dia hamil lagi?)

Penutur 2: iye ne sa ge beteng ye, po balei anek ne ma anui ye kan (itu sudah ndakah dia hamil, yang dulu itu anaknya yang anu itu)

Penutur 1: batere du balei ye (begitu juga dia dulu)

Penutur 2: iya (iya)

Data tersebut adalah percakapan yang berlangsung antara tiga penutur suku Bajau Samma yang membicarakan kondisi salah satu warga yang sakit. Penutur (1) bertanya apa kabarnya orang yang sakit tersebut penutur (1) bertanya menggunakan bahas Bajau Samma kemudian penutur (2) menjawab pertanyaan tersebut warga yang sakit tersebut sudah dirawat di rumah sakit.
Tuturan tersebut termasuk pada penggunaan bahasa antara tetangga.

Dibuktikan dengan percakapan mereka yang menanyakan kondisi salah satu warga yang mengalami sakit dan tuturan tersebut dilakukan di ranah ketetanggaan. penggunaan bahasa pada ranah ketetanggaan terutama pada situasi informal seperti bersenda gurau, membicarakan masalah pribadi, dan bertamu. Bahasa Bajau Samma masih dominan digunakan dibanding bahasa Indonesia. Bahasa Bajau Samma sebagai bahasa ibu menciptakan suasana akrab antar warga.

\section{SIMPULAN}

Berdasarkan hasil penelitian dan pembahasan dapat disimpulkan bahwa upaya yang dilakukan untuk mempertahankan bahasa Bajau Samma berdasarkan faktor- faktor pemertahanan bahasa adalah (1) Kosentrasi Penutur ditemukan 3 data, (2) Kesinambungan pengalihan bahasa ibu 7 data, (3) Loyalitas Terhadap Bahasa Ibu 7 data, (4) Sikap Bahasa Golongan Muda 5 data (5) Penggunaan Bahasa Oleh Kelompok (Guyup) 12 data. Dari jumlah data upaya pemertahanan bahasa yang di lihat dari faktor- faktor pemertahanan bahasa data yang paling banyak di temukan adalah faktor pemertahanan bahasa penggunaan bahasa oleh kelompok guyub yaitu 12 data dan data yang paling sedikit adalah sikap bahasa golongan muda yaitu 5 data.

Pemertahanan bahasa Bajau Samma dimulai dari hal terkecil yakni diri sendiri dan ranah keluarga yang merupakan bagian utama untuk mendukung kelestarian bahasa Bajau Samma. Bagi masyarakat suku Bajau yang tinggal di kelurahan Jenebora Kecamatan Penajam Kabupaten Penajam Paser Utara, hendaknya untuk terus bangga akan identitas diri jangan sampai merasa diri tertinggal oleh jaman modern karena masih mempertahankan bahasa daerah. Selanjutnya, penelitian ini dapat 
dijadikan sebagai kerangka acuan penelitian lanjutan, seperti pilihan bahasa, bentuk pemertahana dan aspek kebahasaan lainnya untuk menambah khasanah ilmu bahasa, khususnya sosiolinguistik.

\section{DAFTAR PUSTAKA}

Ariafianti, I. (2012). Jurnal Ilmiah Cendekia. Retrieved maret 1, 2018. Jurnal Ilmiah Cendekia: http://jurnal.unikal.ac.id/index.ph p/dekia/article/view/311/0.

Chaer, A. \&. (2010). Sosiolinguistik Perkenalan Awal. Jakarta: Rineka Cipta.

Mahsun, M. (2012). Metode Penelitian Bahasa. Jakarta: PT Raja Grafindo Persada.Moleong, L. (2014). Metodologi Penelitian Kualitatif. Bandung: Remaja Rosdakarya.

Nugroho, A. (2014). Suku Bajau, Penjelajah Air Terakhir di Indonesia yang Mulai Hadapi Kepunahan. Retrieved Mei 1, 2018, from www.Boombastis.com:https://w ww.boombastis.com/suku-bajauindonesia/56466.

Nugroho, H. (2016). Pemertahanan Bahasa Sebagai Startegi Komunikasi . Jurnal Bahasa, Seni, dan Pengajaran, , vol 1 no 1 hal 5.

Rahman, R. (2017). Pola-Pola strategi Pemertahanan Bahasa Bali di Desa Palajau Baru Kecamatan Kelupang Hilir Kabupaten Kota baru. Jurnal Bahasa, Sastra Dan Pembelajarannya , 17-19.

Ratna, I. \&. (2003). Budaya Bajau : Pemanfaatan dan Pelestarian Lingkungan. Jurnal Masyrakat dan Budaya, vol 5 no.2 , 59-75.

Sailan, Z. (2014). Pemertahanan Bahasa Muna di Kabupaten Muna Sulawesi Tenggara. Retrieved Maret 1, 2018, from Jurnal Litera. Vol 13 hal. 142:
Http:/www.jurnal.uny.ac.id.

Sugiyono. (2015). Metode Penelitian Pendidikan: pendekatan Kuantitatif, Kualitatif dan R\&D. Bandung: Alfabeta.

Sujarweni, V. (2014). Metodologi Penelitian. Yogyakarta: Pustaka Buku Press. Sumarsono. (1993). Pemertahanan Bahasa Melayu Loloan di Bali. Jakarta: Pusat Pembinaan dan Pengembangan Bahasa.

Sumarsono. (2017). Sosiolingustik. Yogyakarta: Pustaka Pelajar.

Ulfatin, N. (2014). Metode Penelitian kualitatif di Bidang Pendidikan: Teori dan Aplikasinya. Malang: Bayumedia Publishing.

Wijaya, I. \&. (2013). Sosiolinguistik Kajian Teori dan Analisis. Surakarta: Pustaka Pelajar.

Wikipedia. (2010). Rumpun bahasa Sama-Bajau. Retrieved Mei 1, 2018, from Wikipedia.com: https://id.wikipedia.org/wiki/Ru mpun_bahasa_Sama- Bajau.

Wikipedia.com. (2010, Januari 1). Wikipedia. Retrieved April 1, 2018, from Wikipedia: https://id.wikipedia.org/wiki/Bah asa_Indonesia.

Yusri \& Amri, H. (2018). Pemertahanan Bahasa Leukon di Kabupaten Simeulue. Jurnal Dedikasi Pendidikan, vol.2, no.1 , 14-20. 